\title{
THE AUTHORS OF ARTICLES IN THIS
}

NUMBER OF THE HARVARD

THEOLOGICAL REVIEW

JACOB LOEWENBERG, Ph.D., Assistant Professor of Philosophy, University of California.

Author: Hegel's Entwürfe zur Enzyklopädie und Propädeutik; The Writings of the Late Josiah Royce, Ed. (in preparation).

WILLIAMS ADAMS BROWN, Ph.D., D.D., Professor of Systematic Theology, Union Theological Seminary; President of the Union Settlement Association; Vice-President of the Religious Education Association; Secretary of the General War Time Commission of the Churches.

Author: The Essence of Christianity; Christian Theology in Outline; Modern Theology and the Preaching of the Gospel; Is Christianity Practicable? Life of Morris $K$. Jesup; Modern Missions in the Far East.

FRANCIS JOHN McCONNELL, Ph.D., D.D., LL.D., Bishop of the Methodist Episcopal Church; President of the Religious Education Association.

Author: The Diviner Immanence; Religious Certainty; Christian Focus; The Increase of Faith; Personal Christianity; Understanding the Scriptures.

FREDERICK JOHN FOAKES-JACKSON, D.D.; Professor of Christian Institutions, Union Theological Seminary; Fellow of Jesus College, Cambridge (Eng.); Hon. Canon of Peterborough Cathedral.

Author: A History of the Christian Church to A.D. 460;A Biblical History of the Hebrevs; Christian Difficulties in the Second and Twentieth Centuries; Biblical History for Schools (with Rev. B. T. D. Smith); Society in England, 1750-1850; St. Luke and a Modern Writer; Christ in the Church (Cambridge Theological Essays); Richard Hooker (Cambridge History of Literature); The Rise of the Papal Power (Cambridge Mediaval History).

\section{PRESERVED SMITH, Ph.D.}

Author: Luther's Table Talk, A Critical Study; Life and Letters of Martin Luther; Luther's Correspondence and other Contemporary Letters-Two Vols. (Vol. II with C. M. Jacobs); Conversations with Luther, tr. (with H. P. Gallinger). 


\section{Andover Theological Seminary}

Cambridge, Massachusetts

AFFILIATED WITH HARVARD UNIVERSITY

A professional training-school for Christian Ministers, with a three years' course of study leading to the degree of Bachelor of Divinity. Courses in all departments of Theology, with liberal privilege of election. Students have access to courses offered by the Harvard Divinity Faculty and by the Faculty of Arts and Sciences.

For Catalogues and information apply to

THE PRESIDENT OF THE FACULTY, Cambridge, Mass. 